\title{
Empirical Study of Toyota Motor Corporation Relative to the Good to Great Framework
}

\author{
Nicholas Loyd (Corresponding author) \\ Center for Management and Economic Research \\ The University of Alabama in Huntsville \\ 301 Sparkman Dr., Huntsville, Alabama 35806, United States \\ E-mail: Nicholas.Loyd@uah.edu
}

Received: April 24, 2016

Accepted: May 30, 2016 Published: July 1, 2016

10.5296/jmr.v8i3.9374

URL: http://dx.doi.org/10.5296/jmr.v8i3.9374

\begin{abstract}
Best-selling business bookGood to Great was published in 2001 as the result of an effort to understand what characteristics, if any, companies who experience an extended run of greatness have in common compared to companies who do not. The resulting seven-component framework of Good to Great has brought the book both wild acclaim in management circles and heavy scrutiny in the research arena. While the book originally studied only American companies, this research will examine Good to Great's research methodology and definition of "great" in order to compare the framework to Toyota Motor Corporation. A consistent tenant in Fortune's Global 500 top 10, Toyota is arguably one of the most successful companies in the world, showing a growth that has been remarkably steady for almost 80 years. This paper examines empirical data and evidence from Toyota research and analyses the degree of fit relative to the Good to Great framework. The outcome of the paper offers evidence to support Good to Great framework by putting it on trial against a large international organization.
\end{abstract}

Keywords: strategy, management, business, Toyota, lean, operations management 


\section{Mll Macrothink}

\section{Introduction}

Best-selling management author Jim Collins, driven by criticism of his previous publication Built to Last, set out to answer a question: why do some companies make the leap to greatness while others do not? The result was a five-year research project that combed through data from over 1400 U.S. companies spanning over 40 years (J. Collins, 2001).

\subsection{The Good to Great Framework}

Eleven companies survived the cut and met the research team's definition of "great;" this definition will be discussed in the next section. Those eleven companies were then examined for common characteristics during their respective era of greatness. All eleven companies shared only seven characteristics, and these seven components now make up the framework presented in the book that shares the findings of the research project: Good to Great- Why Some Companies Make the Leap While Others Don't (J. C. Collins, 2001). The framework is comprised of the following components: Level 5 Leadership, First Who...Then What, Confronting the Brutal Facts, the Hedgehog Concept, Culture of Discipline, Technology Accelerators, and The Flywheel/Doom Loop. Figure 1 shows the seven components of the Good to Great Framework.

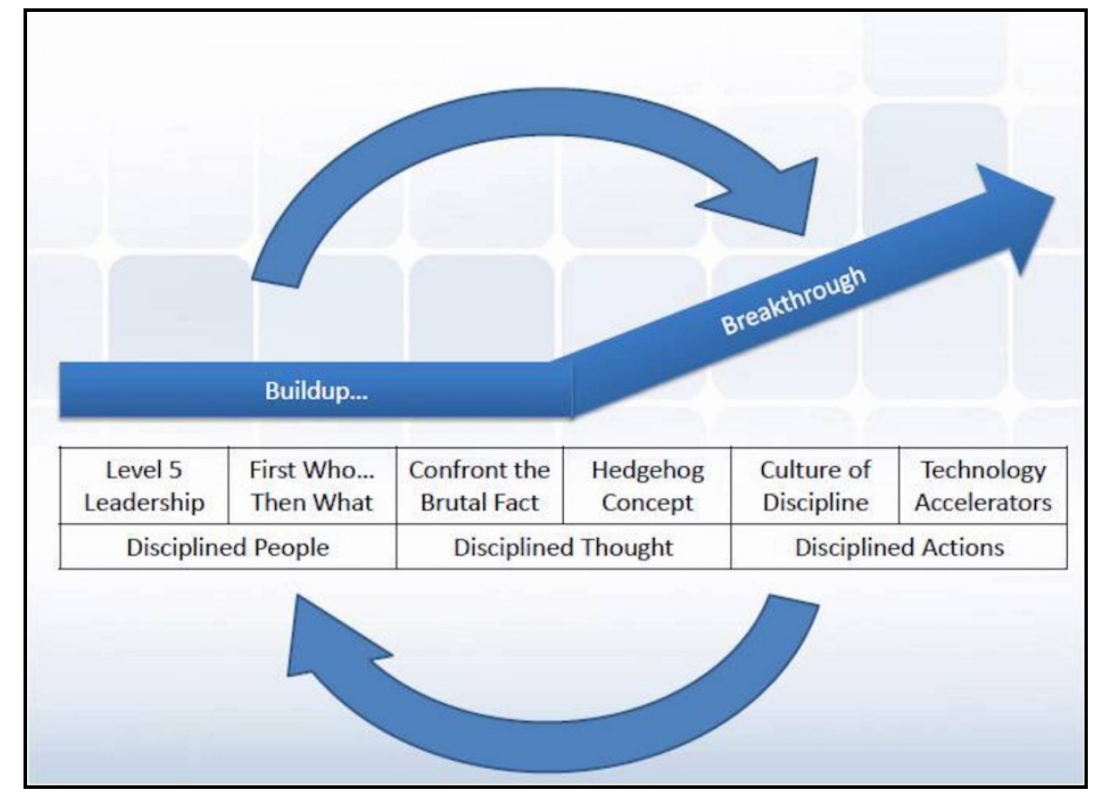

Figure 1. The Seven Components of the Good to Great Framework

Good to Great received high acclaim almost immediately upon its 2001 release. The book had long stints at number one on most of the prestigious best seller lists and has sold almost five million hardback copies (Bryant, 2009). Wall Street Journal executives called it the best business book they had ever read (Murray, 2010). However, criticism of the book began to accumulate almost as quickly as the praise. Most commonly, critics cited the book's research methods (Rosenzweig, 2007), the fact that some of the "great" companies have since been relegated to a state of irrelevance or extinction (Levitt, 2008), and questioned the applicability of the Good to Great framework outside of its U.S. sample companies. This 
research effort will address the latter issue by investigating empirical evidence of the Good to Great framework in an international company who has sustained almost 80 years of steady growth while dominating its industry- Toyota Motor Corporation (Magee, 2007).

\subsection{Toyota Motor Corporation}

Toyota Motor Corporation had humble beginnings as Toyota Motor Company in 1937, founded by Kiichiro Toyoda as a spin off of his father Sakichi's automatic loom company (J. K. Liker, 2004). After World War II, the company was in serious crisis and faced mounting debt. This debt led to a major restructuring of the company and the beginning of the development of the Toyota Production System (TPS) (J. K. Liker, 2004). TPS would drive the company's rebound to profitability, give it a critical advantage during the oil crisis of the 1970s, and ultimately place the company at the top of the automotive industry (Ōhno, 1988). Today, Toyota Motor Corporation is Japan's largest company, the world's eleventh largest company, and the number one company in the highly-competitive automotive industry (OICA, 2008-2014). Toyota's profits for automotive calendar year 2014 were more than the U.S. big three- General Motors, Ford, and Chrysler- combined (Wayland, 2015). The Toyota Production System, the primary inspiration for what is commonly known as Lean production outside of Japan (Womack, Jones, Roos, \& Massachusetts Institute of Technology., 1990), has been studied and imitated in almost every industry.

Toyota's success can be demonstrated ad nauseam with their financial performance, their production and quality excellence, and the influence TPS has made on the business world. Jeffrey Liker, who has studied Toyota for over 30 years and written numerous books on the company, referred to Toyota as "the world's greatest manufacturer" (J. K. Liker, 2004). Thus, the objective of this research is to investigate the degree to which Toyota Motor Corporation's greatness matches up to the framework of Good to Great. The two primary research questions are:

- Does Toyota Motor Corporation fit Good to Great's criteria for being a Good to Great company?

- Does the Good to Great framework accurately reflect the strategy and culture of Toyota Motor Corporation?

\section{Analysis of the Good to Great Framework vs. Toyota}

\subsection{Definition of Great}

When Jim Collins and his research staff set out to identify why only some companies make the leap to greatness, they first had to define what "great" actually meant. This definition has become one of the strongest criticisms of the book (May, 2006), but must serve as the baseline for comparison in this article. Good to Great used the following criteria to qualify companies as "good to great" (J. C. Collins, 2001):

- Fifteen years of cumulative stock returns at or below the general stock market,

- Punctuated by a transition point, 
- Followed by at least fifteen years of cumulative stock returns at least three times the general market

Toyota stock began to be publicly traded since 1949. The time period from 1999-2013 is the 15-year stretch where Toyota's stock performance most closely exhibited Good to Great's criteria. One U.S. dollar invested in Toyota Motor Corporation at the beginning of 1999 yielded \$2.53, 153\% growth, by the end of 2013 (Finance.yahoo.com). Comparatively, one dollar invested in the S\&P 500 over the same timeframe yielded $\$ 1.50$, or $50.4 \%$ growth (DQYDJ.net, 2015). The S\&P 500 is a stock index designed by Standards and Poors Financial Services to be a leading indicator of the U.S. stock market; it is considered by many to be the best representation of the status of the U.S. economy ("Standard \& Poor's 500 Index - S\&P 500," 2012). Thus, for this 15-year span Toyota outperformed the market by $303 \%$, above the requirement set forth in Good to Great. In the 15 years leading up to 1999, 1984 to 1998, Toyota only performed at $78 \%$ of the S\&P 500 index, which also fulfils the Good to Great requirement. Table 1 shows the summary of stock return data used for this research's calculations. Full stock data can be found in Appendix 1.

Table 1. Stock Price Summary

\begin{tabular}{|c|c|c|c|c|}
\hline & & Toyota [TM] & $\begin{array}{l}\text { S\&P } 500 \\
{\left[{ }^{\wedge} \mathrm{GSPC}\right]}\end{array}$ & Ford $[F]$ \\
\hline \multirow{5}{*}{$\begin{array}{l}\text { Pre-Good to } \\
\text { Great Era } \\
(1984-1998)\end{array}$} & 1984 start price & $\$ 7.99$ & $\$ 164.93$ & $\$ 0.91$ \\
\hline & 1998 end price & $\$ 48.25$ & $\$ 1,229.23$ & $\$ 21.56$ \\
\hline & $\begin{array}{l}15 \text { year cumulative } \\
\text { return }\end{array}$ & $504 \%$ & $645 \%$ & $2269 \%$ \\
\hline & Return on $\$ 1$ invested & $\$ 6.04$ & $\$ 13.97$ & $\$ 23.69$ \\
\hline & Return vs. S\&P & $78 \%$ & & $352 \%$ \\
\hline \multirow{5}{*}{$\begin{array}{c}\text { Good to } \\
\text { Great Era } \\
(1999-2013)\end{array}$} & 1999 start price & $\$ 48.25$ & $\$ 1,229.23$ & $\$ 21.56$ \\
\hline & 2013 end price & $\$ 121.92$ & $\$ 1,848.36$ & $\$ 14.36$ \\
\hline & $\begin{array}{l}15 \text { year cumulative } \\
\text { return }\end{array}$ & $153 \%$ & $50 \%$ & $-33 \%$ \\
\hline & Return on $\$ 1$ invested & $\$ 2.53$ & $\$ 1.50$ & $\$ 0.67$ \\
\hline & Return vs. S\&P & $303 \%$ & & $-66 \%$ \\
\hline
\end{tabular}

A summary of the stock prices for Toyota, the S\&P general market, and comparison company Ford.

In addition to a company's individual performance, Good to Great also used a comparison company from the same industry and era to ensure ascension was not industry-specific. While it would be easy to compare Toyota to General Motors and Chrysler, both of whom filed for bankruptcy during this era, this research chose Ford Motor Corporation for comparison. During the timeframe of interest, Ford performed at $-66 \%$ of the S\&P index, with $\$ 1$ being invested in 1999 being worth $\$ 0.66$ at the end of 2013 (Finance.yahoo.com). While Toyota's greatness stands alone due to its superior profits, volumes, and market value within its 


\section{Macrothink Institute ${ }^{T M}$}

industry, it is important to note data supports the company's qualification as a Good to Great company based on the same set of performance criteria used in the original study. Figure 3 shows a comparison of Toyota, the S\&P 500 and Ford stock returns from 1984-1998. Figure 4 shows a comparison of Toyota, the S\&P 500, and Ford stock performance from 1999-2013.

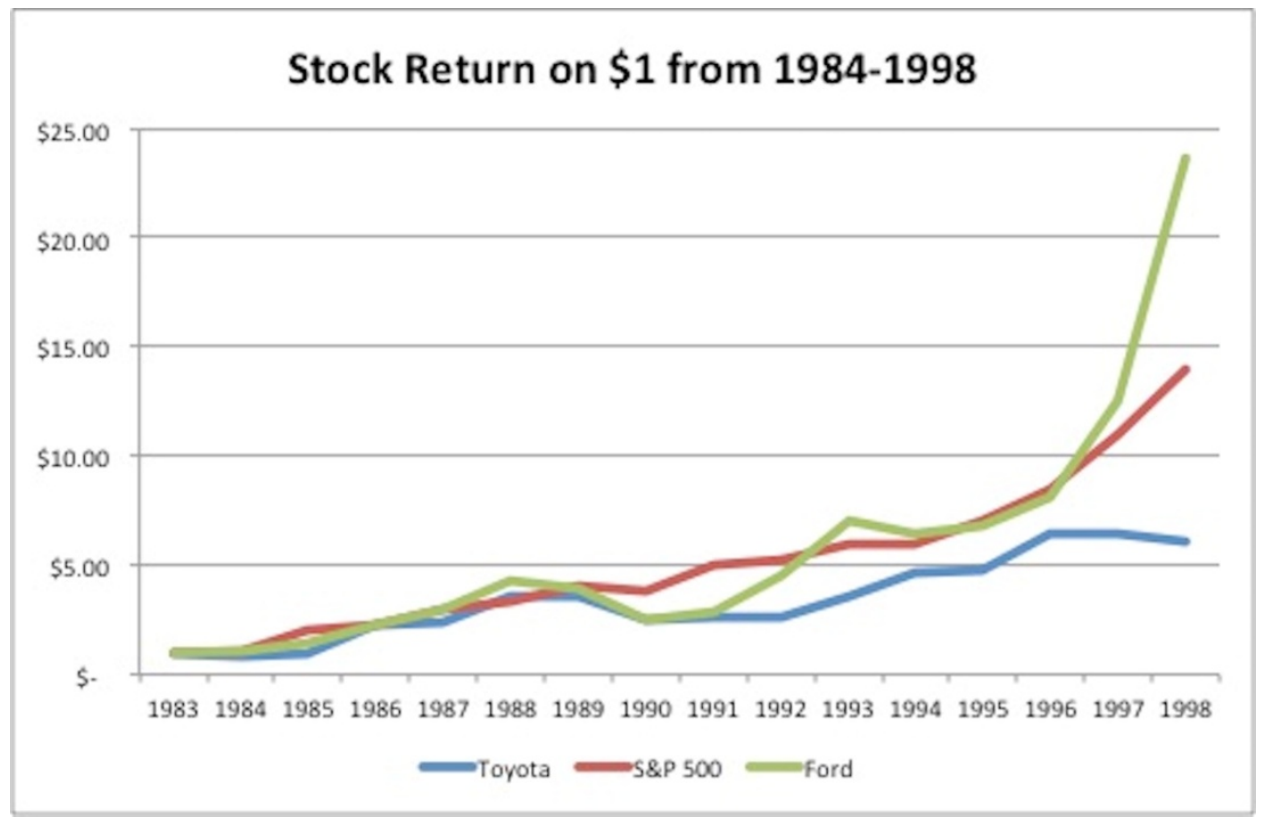

Figure 2. Graphed Comparison of Stock Performance in Toyota's Pre-Good to Great Era (1984-1998)

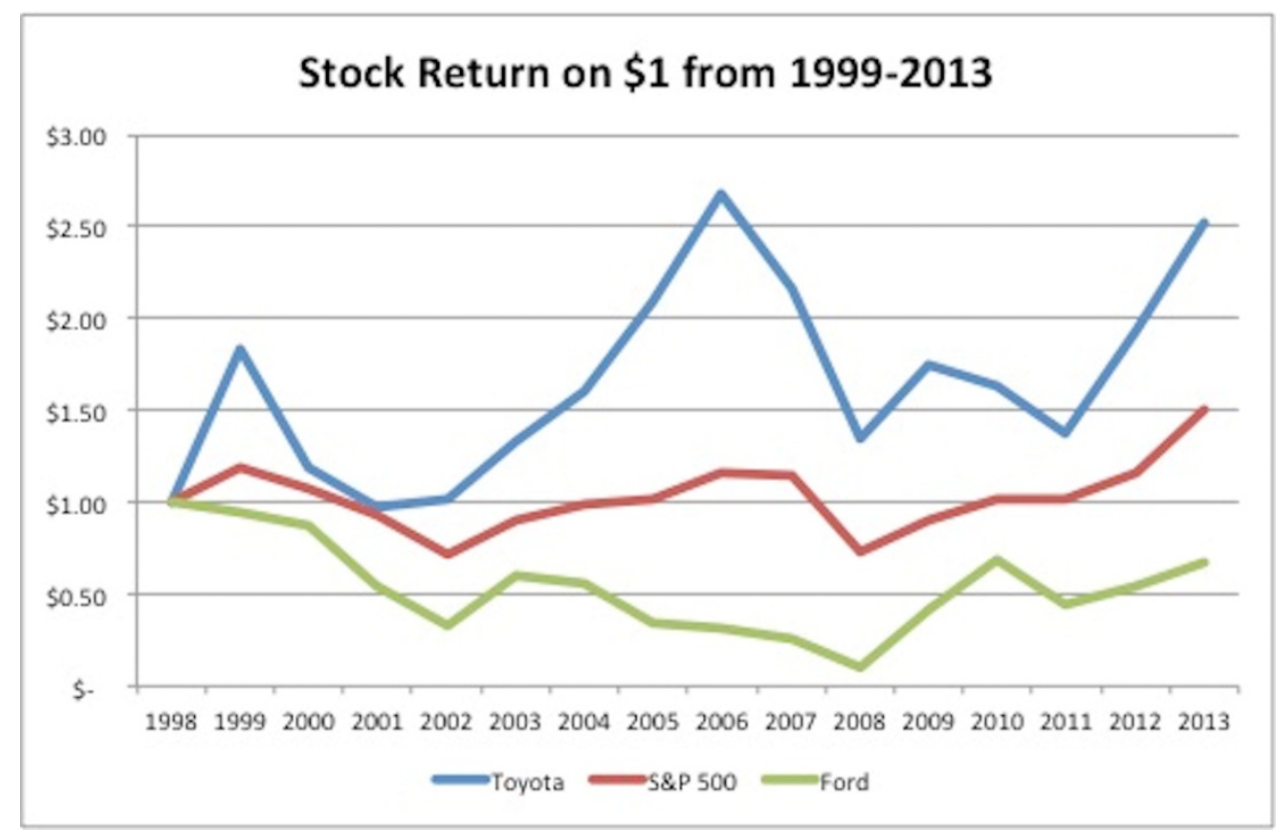

Figure 3. Graphed Comparison of Stock Performance in Toyota's Good to Great Era (1999-2013) 


\subsection{Level 5 Leadership}

One of the more surprising characteristics that was shared by all Good to Great companies was the concept of level 5 leadership- a leadership consisting of both humility and an unwavering resolve to achieve sustainable results (J. C. Collins, 2001). The level 5 leadership style is contrasted specifically with Level 4 leadership- one that is typified by a leader with a big presence and an egotistical personality. Humility is interwoven at every level of leadership at Toyota. When Toyota CEO Fujio Cho unveiled The Toyota Way 2001, an internal document created to standardize Toyota's culture on a global scale, it featured the Japanese term genchi gembutsu as one of its 5 core principles (TMC, 2001). Genchi gembutsu means to go see and understand, and is embodied by Toyota's renown propensity for placing candidates for all leadership positions at the process to work alongside the operators for extensive training (Hoeft, 2010; Obara \& Wilburn, 2012; S. J. Spear, 2004). This allows the leader to both develop a deeper understanding of the working environment, and also develops humility that will serve to prepare them to successfully lead within the company's culture. Other published anecdotes relayed by former Toyota leaders showed evidence of humility in many other ways, included wearing the same uniforms as the operators at some locations, lack of reserved parking for executives, and generally lower compensation at the executive level compared to other companies (Magee, 2007).

Interestingly, Good to Great reveals that 10 out of 11 Good to Great companies had CEOs who were promoted from within the organization; level 4 leaders are often big names hired from the outside to be a larger-than-life super-executive riding in to save the day (and the company). Not surprisingly, all 11 presidents/CEOs of Toyota Motor Corporation (including the three during the Good-to-Great era) have been developed from within. When leaders at other critical positions are brought in from the outside, it isn't done without a very meticulous baptism into the Toyota culture. Gary Convis, the first American president of a Toyota division (Toyota Motor Manufacturing Kentucky) had extensive leadership experience at both Ford and GM. Once Convis was hired at Toyota, he was groomed and mentored for over 15 years before winning the trust of the company to eventually lead its largest manufacturing facility outside of Japan (J. K. Liker, 2004). In accordance to the characteristics of level 5 leadership, Toyota does not seek to purchase successful leaders from the outside to come in and save the day; the company depends on its deeply engrained culture of respect and humility to develop leaders from within.

A telling analogy presented in Good to Great stated "a level 4 leader looks in the mirror to take credit and looks out the window to place blame; a level 5 leader looks out the window to give credit and looks in the mirror to place blame" (J. C. Collins, 2001). In 2009, an accident involving a seemingly faulty accelerator caused a tragic accident and kicked off a massive string of Toyota recalls, investigations, and testimonies before the U.S. Congress. Toyota President Akio Toyoda, in his first appearance before congress, chose to accept blame and use the opportunity to deliver information to Toyota's customers, suppliers, and partners as opposed to taking a more arrogant, combative and defensive approach. Ultimately, after over 2 million recalls, independent research would find that zero accidents were caused due to any mechanical or electronic-based error on Toyota's part. Level 5 leadership was perfectly 
demonstrated as Toyoda looked in the mirror and accepted blame, even when there was no blame to be dealt (J. K. Liker \& Convis, 2012).

\subsection{First Who...the What}

This element of the Good to Great framework focuses on the adage that people are not an organization's most important asset- the right people are. The concept revolves around getting the right people on the bus, getting them in the correct seat, and then deciding where to drive the bus. Good to Great companies, it is reported, invest in getting the right people in the organization, developing them, and letting human capital determine ultimate direction (J. C. Collins, 2001). This supports research that shows that it is motivated people who drive the success of problem solving more than any technical problem solving methodology on its own (Chlpekova, Vecera, \& Surinova, 2014).

Perhaps no other organization in history has placed a higher emphasis on people development than Toyota. One of the two major pillars of the Toyota Way 2001, along with continuous improvement, is respect for people (TMC, 2001). However, for those who have deeply researched Toyota, the term respect in the company takes on a different meaning versus what many Western companies consider respect. At Toyota, respect does not mean individual freedom at work, plush job perqs, or a relaxed work environment. Toyota's respect for people revolves around the expectation that employees contribute to problem solving at all levels (S. Spear \& Bowen, 1999), which requires an extensive training and development system (J. Liker \& Meier, 2007). In return Toyota rewards this investment with a policy of having no involuntary layoffs- a policy the company has not deviated from; during Toyota's Good to Great era it had zero involuntary layoffs in spite of dramatic instability in the global economy, quality recalls, and natural disasters (J. K. Liker \& Convis, 2012). A 2014 study of the Toyota Way 2001 pillars of continuous improvement and respect for people, by Jayamaha et al., suggests that continuous improvement- the what that drives the Toyota Production System - does, indeed, not happen without people development- the who (Jayamaha, Wagner, Grigg, Campbell-Allen, \& Harvie, 2014).

\subsection{Confront the Brutal Facts}

Good to Great's research uncovered a unique trait among companies relative to how they handled adversity. Good to Great companies shared persistence in facing the brutal facts of their reality, as opposed to using denial or excuses to distract from such threats. The framework presents this concept as being characterized by leading with questions, engaging in truthful dialogue, and instituting red flag mechanisms to make issues obvious (J. C. Collins, 2001).

From 2008-2010 Toyota faced a trifecta of potentially catastrophic events- the 2008 global recession, the aforementioned 2009 quality recalls, and the 2010 earthquake and tsunami in Japan- the country's worst natural disaster in history. While any one of such events could have, and did, relegate many companies to bankruptcy or extinction, Toyota faced each brutal reality head on. During the 2008 global recession, Toyota experienced drastic sales drops equivalent to the rest of the automotive industry. However, the company was able to 
persevere due to wise investments and the corporation's strategy to be self-sufficient and relatively debt free. However, by using leading questions of its operations, the company realized that it had let its inventory grow excessively. In efforts to adjust inventory levels back to appropriate levels, production was halted for an entire quarter. However, holding with company policy, no full time positions faced involuntary layoffs. Toyota's management strategy allowed it to face the brutal reality of the global recession while having faith that it would return to prosperity afterward (J. K. Liker \& Convis, 2012).

Akio Toyoda utilized truthful dialogue to address the 2009 recall crisis by using his testimony before congress to disseminate information to customers and business partners. While the external investigations eventually showed no technical defect from Toyota caused any accidents, Toyota's internal autopsy revealed several cases of communication errors and unacceptable response times to customer concerns. Instead of using excuses or blame, the company once again faced the brutal facts of its reality and sought to correct the issues at the root cause level (J. K. Liker \& Convis, 2012).

The concept of implementing red flag mechanisms to quickly identify problems is nothing new to Toyota. Toyota Motor Corporation spun off from Toyota Spinning and Weaving, which was owned by Sakichi Toyoda. Sakichi was a renowned inventor; in addition to inventing the first automatic loom, he also developed a device that would automatically stop when a strand of yarn was broken. When Sakichi's son Kiichiro started up Toyota Motor Company, this principle was immediately adopted. This concept is known as jidoka, or automation with a human touch (Ōhno, 1988). Any employee at Toyota has the authority to stop the production line if they discover a problem. Additionally, employees are trained to problem solve and address issues at the root cause (S. Spear \& Bowen, 1999). Toyota's system insists that problems ranging from minor errors to major quality recalls be faced as they happen; this the epitome of confronting brutal facts.

\subsection{Hedgehog Concept}

Interestingly, Good to Great concluded that strategy had very little to do with a company making the leap to great, as evidence of strategy was found in both companies who made the leap and those who did not. Additionally, it was concluded that a company did not have to be in a great industry to become great. Instead, it was adherence to a "hedgehog concept"- an understanding of about what a company is passionate, what drives its economic engine, and at what it can be best in the world- that surfaced. Good to Great companies remained focused on made them successful while their comparison companies often deviated into unfamiliar ventures (J. C. Collins, 2001).

Toyota utilizes its own unique planning process, hoshin kanri, to ensure that its corporate strategy is aligned throughout the organization (Dennis, 2007). However, since Good to Great research did not find the existence of strategy significant, this article will not go into depth on this process. However, it is curious to analyze Toyota versus the idea of the hedgehog concept. Good to Great presents that a company's hedgehog concept consists of three factors- at what can it be best in the world, about what is the company passionate, and what drives the company's economic engine. As discussed earlier, it is easy to make the argument that what 


\section{Macrothink}

Journal of Management Research

ISSN 1941-899X

2016, Vol. 8, No. 3

Toyota is best at is making automobiles. The company is number one in the world in profit, volume, and market value.

A deeper question might be required in order to address the second component of the hedgehog concept- about what is Toyota passionate? This research suggests the answer is the development of people. Even in the very first writing on the Toyota Production System, Sugimori et al. (Sugimori, Kusunoki, Cho, \& Uchikawa, 1977) expounded on the importance of the workers' development and display of abilities- to be authorized to stop the production line when needed, and run their own workshops to eliminate wastes- in the success of the overall system. A common mantra at Toyota is "we do not just build cars; we build people" (J. Liker \& Meier, 2007). Toyota often spends an average of 6 weeks teaching an operator to do a 60 -second job (Hoeft, 2010). In addition, employees are also developed to problem solve and lead improvement teams. Not only are workers trained to perform and improve their jobs, they are also trained and developed to coach and develop other people (J. Liker \& Meier, 2007; Rother, 2010). In the eyes of this research, Toyota certainly displays passion about people development.

The third component of the hedgehog concept- what drives the economic engine- is very clear for Toyota. The goals of the Toyota Production System from the beginning (Ōhno, 1988; Sugimori et al., 1977) have been openly stated- build the automobile at the lowest cost, best quality, and shortest lead time to the customer while also providing the safest and most respectful work environment for employees. The five elements of cost, quality, delivery, safety, and respect have been consistent in later Toyota research (Dennis, 2007; Hoeft, 2010) and are certainly what drives the corporation's economic engine during its planning efforts (Dennis, 2006). Whether or not leadership at Toyota realizes what hedgehog concept is, the company definitely exhibits the three components as defined by Good to Great. Toyota's hedgehog concept might look like Figure 4 


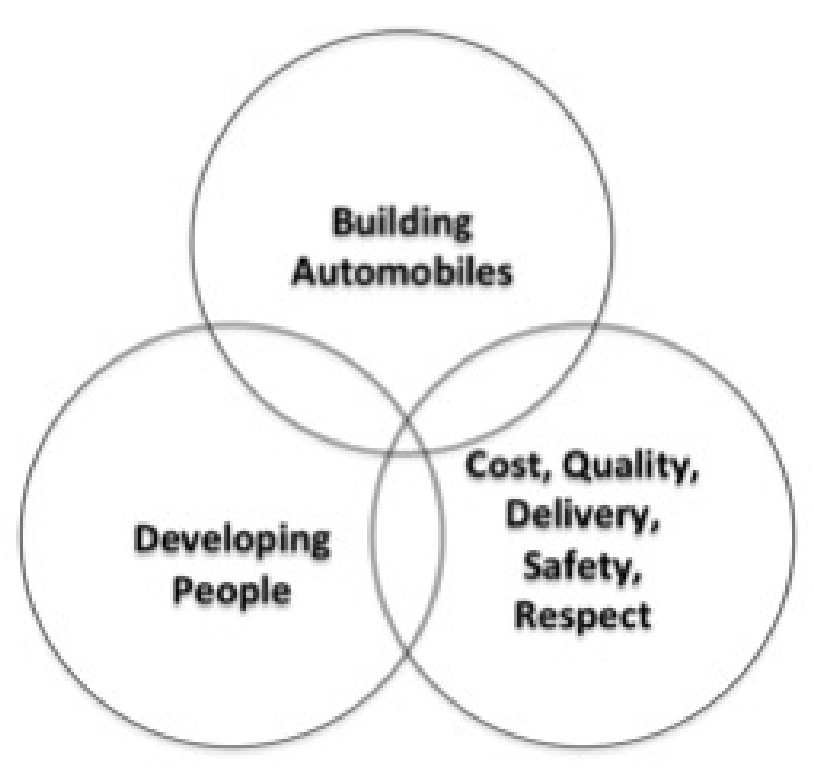

Figure 4. Hypothetical Hedgehog Concept for Toyota

\subsection{Culture of Discipline}

The culture of discipline concept is defined in Good to Great as having disciplined people engaged in disciplined thought and taking disciplined action. According to Good to Great, this discipline should be focused around a strict adherence to the hedgehog strategy (J. C. Collins, 2001).

The idea of a culture of discipline at Toyota begins with its fanatic emphasis on standardization. Standardization is the foundation of the Toyota Production System (Dennis, 2007) and is viewed as being necessary in order to identify problems and improve its processes. When Spear's (S. Spear \& Bowen, 1999) 1999 research identified the four rules that made up the DNA of the TPS, all four revolved around having a culture of highly-specified work and a workforce of problem solvers to adjust when processes are out of standard. Mike Rother, who has published research on Toyota for over two decades, compared Toyota's culture to the discipline of martial arts; Rother called the day-to-day disciplined mind set of the workforce as the Toyota kata (Rother, 2010). In martial arts, a kata is a set of precise, routine actions practiced repeatedly so that the disciplined actions become second nature. The Toyota culture fosters this same disciplined routine in the way employees are trained to think and act in their jobs. This disciplined organizational culture has shown to be an enabler for knowledge creation and transfer, which is an accurate reflection of an organization's growth and prosperity (Nair, Ramalingam, \& Ravi, 2015).

\subsection{Technology Accelerators}

Good to Great companies avoided falling prey to technology fads, yet embraced carefully selected technologies to accelerate existing processes (J. C. Collins, 2001). While other 
companies often rely on technology to be a quick answer or silver bullet, none of the Good to Great companies began their ascent based on pioneering technology. In Toyota Production System, TPS pioneer Taiichi Ohno addressed the use of information technology directly (Ōhno, 1988). The kanban scheduling system developed at Toyota is purposely visual and manual, as opposed to computer-driven, in order to deliver information only as needed. Ohno stated:

"At Toyota, we do not reject the computer, because it is essential to planning production levelling procedures and calculating the number of parts needed daily. We use the computer freely, as a tool, and try not to be pushed around by it. But we reject the dehumanization caused by computers and the way they can lead to higher costs." (Ōhno, 1988)

Toyota's philosophy on the use of technology is further described in The Toyota Way's 14 management principles (J. K. Liker, 2004). Principle 8 is to use only reliable, thoroughly tested technology that serves your people and processes. Toyota does not exclude technology, but carefully chooses the right technologies to accelerate and support its existing processes. This principle is summed up with a simple statement: people do the work, computers move the information (J. K. Liker, 2004).

\subsection{The Flywheel and the Doom Loop}

While the transition from good to great seemed drastic to those on the outside, those on the inside did not realize anything special was occurring. The changes occurred gradually over time, each building more and more momentum. By contrast, the companies who did not make the leap to great had a tendency to grasp at flashy programs, restructuring, or big name hires. When immediate success did not prevail, reactions were repeatedly taken to adjust and gradually tumble downward (J. C. Collins, 2001).

One could argue that the idea of continuous improvement has been mastered by Toyota. As stated earlier, continuous improvement- along with respect for people- is identified as one of the main pillars of the Toyota Way 2001 culture (TMC, 2001). The bridge between the two pillars is the Japanese idea of kaizen- everyone on every level making small, gradual improvements every day (Dennis, 2007). The previously mentioned Toyota kata (Rother, 2010) reaffirms that Toyota's success is not driven by large, drastic changes, but instead by the disciplined actions of the workforce to constantly make incremental change to drive toward the ideal situation- a process that contains zero non-value-added steps. The pillar of continuous improvement is the element that drives Toyota's flywheel to facilitate the level of success the company has achieved. The systematic application of the Toyota Production System reflects findings that a structured operations management system leads to improved organizational performance (Battistoni, Bonacelli, Colladon, \& Schiraldi, 2013).

\section{Conclusion and Discussion}

\subsection{Conclusions from this Study}

The objective of this research was to answer two questions, a) does Toyota Motor Corporation fit Good to Great's criteria for being a Good to Great company, and if so b) does 
the Good to Great framework accurately reflect the strategy and culture of Toyota Motor Corporation? The findings of this research suggest the answers to both of those questions could very well be an affirmative.

To assess if Toyota met the criteria for a Good to Great company, all available stock return data was analysed for Toyota, the general stock market (in this case, represented by the S\&P 500 index), and a comparison company from its industry (in this case, Ford). The finding was the Toyota did meet the criteria by exhibiting a period of at least 15 years performing at or below the market average (1984-1998 at 78\% of the market average) followed by a period of 15 years outperforming the market by at least three times (1999-2013 at 303\% of the market average). Additionally, Toyota met the criteria of also having its comparison company fail to outperform the market during the same era. There were other secondary criteria outlined in Good to Great(J. C. Collins, 2001) that Toyota also met, but was not discussed in this report.

Upon confirmation that Toyota met the criteria of a Good to Great company, the second objective was to evaluate the Good to Great framework against empirical evidence of Toyota's strategy and culture. Solid evidence was identified suggesting that each of the seven components of the framework exist within Toyota's culture, and especially existed during the company's Good to Great era. Many components of the framework such as the flywheel effect and a culture of discipline were easily related to existing Toyota principles of continuous improvement and standardization. However, even abstract concepts that were developed during the original Good to Great research, such as the hedgehog concept, were readily identified in Toyota research. This research concludes that Toyota Motor Corporation both meets the criteria and shows strong evidence of the framework of a Good to Great company.

\subsection{Discussion}

The intent of this research was never to put Toyota's greatness on trial, as it was stated often that the objective data of sales, volume, and market value speak on its own. Instead, this research sought to take the fixed variable of Toyota's success and use it to evaluate the theory of Good to Great. In doing so, it was concluded that the framework held up adequately. This offers research contributions in a couple of different manners.

First, the fact such research was performed to compare Toyota's documented success to the methodology of Good to Great, and the results suggesting there is a good fit to the between the two can only weigh positively on the side of validating the book's theoretical model. While some of Good to Great's criticized research methods were not addressed in this work, the analysis of the output was still favorable in regard to the framework. Additionally, the fit of the framework with a company with the history of success of Toyota dampens some of the criticism of the framework's strength. While the fact that some of the Good to Great companies from the original study have faltered is certainly noteworthy; however, this research helps support the argument that the Good to Great model, much like the Toyota Production System, is more about adhering to the process and less about the name of the actual company. 
Finally, this is first known research to evaluate the Good to Great framework against an international company. The original study focused only on U.S. companies, primarily due to the readily available stock return information for that population. Broadening the original study to include international companies would have been a daunting task. However, with the framework defined it was possible in this research to evaluate it versus an international company such as Toyota. This finding certainly offers additional credibility for companies hoping to use the theory of Good to Great, or the Toyota Production System and Toyota Way for that matter, to improve their business strategy and operations.

\section{References}

Battistoni, E., Bonacelli, A., Colladon, A. F., \& Schiraldi, M. M. (2013). An Analaysis of the Effect of Operations Management Practices on Performance. International Journal of Engineeering Business Management, 5(44).

Bryant, A. (2009). For this Guru, No Question is Too Big. New York TImes. Retrieved from http://www.nytimes.com/2009/05/24/business/24collins.html?_r=1\&pagewanted=all

Chlpekova, A., Vecera, P., \& Surinova, Y. (2014). Enhancing the Effectiveness of Problem-Solving Processes through Employee Motivation and Involvement. International Journal of Engineeering Business Management, 6(31). http://dx.doi.org/10.5772/59431

Collins, J. (2001). Good to Great. Retrieved from http://www.jimcollins.com/article_topics/articles/good-to-great.html

Collins, J. C. (2001). Good to great : why some companies make the leap--and others don't (1st ed.). New York, NY: HarperBusiness.

Dennis, P. (2006). Getting the Right Things Done: A Leader's Guide to Planning and Execution: Lean Enterprise Institute.

Dennis, P. (2007). Lean production simplified : a plain language guide to the world's most powerful production system (2nd ed.). New York: Productivity Press.

DQYDJ.net. (2015). S\&P 500 Return Calculator. Retrieved from http://dqydj.net/sp-500-return-calculator/

Finance.yahoo.com. Ford Motor Co.

Finance.yahoo.com. Toyota Motor Corporation (TM).

Hoeft, S. E. (2010). Stories from my sensei : two decades of lessons learned implementing Toyota-style systems. New York: Productivity Press.

Jayamaha, N. P., Wagner, J. P., Grigg, N. P., Campbell-Allen, N. M., \& Harvie, W. (2014). Testing a theoretical model underlying the 'Toyota Way' - an empirical study involving a large global sample of Toyota facilities. International Journal of Production Research, 52(14), 4332-4350. http://dx.doi.org/10.1080/00207543.2014.883467

Levitt, S. D. (2008). From Good to Great...to Below Average. Freakonomics. Retrieved from http://freakonomics.com/2008/07/28/from-good-to-great-to-below-average/

Liker, J., \& Meier, D. (2007). Toyota Talent: Developing Your People the Toyota Way: McGraw-Hill.

Liker, J. K. (2004). The Toyota way : 14 management principles from the world's greatest 
manufacturer. New York: McGraw-Hill.

Liker, J. K., \& Convis, G. L. (2012). The Toyota Way to Lean Leadership: McGraw Hill.

Magee, D. (2007). How Toyota became \#1 : leadership lessons from the world's greatest car company. New York: Portfolio.

May, R. (2006). Why "Good to Great" isn't Very Good. Business Pundit. Retrieved from businesspundit.com website:

Murray, A. (2010). The Wall Street Journal Essential Guide to Management. New York: HarperCollins.

Nair, A. C., Ramalingam, S., \& Ravi, A. (2015). Knowledge Creation Within the Automobile Industry. International Journal of Engineeering Business Management, 7(16). http://dx.doi.org/10.5772/61090

Obara, S., \& Wilburn, D. (2012). Toyota by Toyota: Reflections from the Inside Leaders on the Techniques that Revolutionized the Industry: CRC Press.

Ōhno, T. (1988). Toyota production system : beyond large-scale production. Cambridge, Mass.: Productivity Press.

OICA, T. I. O. o. M. V. M. (2008-2014). Production Statistics. Retrieved from http://www.oica.net/category/production-statistics/

Rosenzweig, P. (2007). The Halo Effect: ...and the Eight Other Business Delusions that Deceive Managers (Reissue ed.): Free Press.

Rother, M. (2010). Toyota kata : managing people for improvement, adaptiveness, and superior results. New York: McGraw Hill.

Spear, S., \& Bowen, H. K. (1999). Decoding the DNA of the Toyota Production System. Harvard Business Review(September-October).

Spear, S. J. (2004). Learning to lead at Toyota. Harvard Business Review, 82(5), 78-86, 151.

Standard \& Poor's 500 Index - S\&P 500. (2012). Retrieved from http://www.investopedia.com/terms/s/sp500.asp

Sugimori, Y., Kusunoki, K., Cho, F., \& Uchikawa, S. (1977). Toyota production system and Kanban system Materialization of just-in-time and respect-for-human system. International Journal of Production Research, 15(6), 553-564. http://dx.doi.org/10.1080/00207547708943149

TMC. (2001). Globalizing and Localizing Manufacturing.

Wayland, M. (2015). Toyota's Per-Car Profits Lap Detroits's Big 3 Automakers.

Womack, J. P., Jones, D. T., Roos, D., \& Massachusetts Institute of Technology. (1990). The machine that changed the world : based on the Massachusetts Institute of Technology 5-million dollar 5-year study on the future of the automobile. New York: Rawson Associates. 


\section{MInstitute ${ }_{\text {Macrothink }}$}

\section{Appendix}

Appendix 1. Full Stock Analysis Data Set

\begin{tabular}{|c|c|c|c|c|c|c|c|c|c|c|c|}
\hline Year & $\begin{array}{c}\text { TM } \\
\text { EndYRS }\end{array}$ & $\begin{array}{c}1 \mathrm{yr} \% \\
+/-\end{array}$ & $\begin{array}{c}15 \mathrm{yr} \\
\text { cumul. }\end{array}$ & & P End yr\$ & $\begin{array}{c}1 \mathrm{yr} \% \\
+/-\end{array}$ & $\begin{array}{c}15 \mathrm{yr} \\
\text { cumul. }\end{array}$ & $\begin{array}{c}\text { TM vs } \\
\text { S\&P }\end{array}$ & & $\begin{array}{l}\text { Ford } \\
\text { EndYr }\end{array}$ & $1 \mathrm{yr} \%$ \\
\hline 1976 & $\$ 15.29$ & & & p & 107.46 & & & & & & \\
\hline 1977 & $\$ 11.65$ & $-24 \%$ & & $\$$ & 93.82 & $-13 \%$ & & & & & \\
\hline 1978 & $\$ 19.09$ & $64 \%$ & & $\$$ & 96.11 & $2 \%$ & & & & & \\
\hline 1979 & $\$ 14.54$ & $-24 \%$ & & $\$$ & 107.94 & $12 \%$ & & & & & \\
\hline 1980 & $\$ 17.13$ & $18 \%$ & & $\$$ & 135.76 & $26 \%$ & & & & & \\
\hline 1981 & $\$ 23.65$ & $38 \%$ & & $\$$ & 122.55 & $-10 \%$ & & & & & \\
\hline 1982 & 5.88 & $-75 \%$ & & $\$$ & 140.64 & $15 \%$ & & & & & \\
\hline 1983 & 7.99 & $36 \%$ & & $\$$ & 164.93 & $17 \%$ & & & & 0.91 & \\
\hline 1984 & 6.18 & $-23 \%$ & & $\$$ & 167.24 & $1 \%$ & & & $\$$ & 0.96 & $5 \%$ \\
\hline 1985 & 7.98 & $29 \%$ & & $\$$ & 211.28 & $26.3 \%$ & & & $\$$ & 1.27 & $32 \%$ \\
\hline 1986 & \$ 17.71 & $122 \%$ & & $\$$ & 242.17 & $14.6 \%$ & & & $\$$ & 2.01 & $58 \%$ \\
\hline 1987 & $\$ 19.04$ & $8 \%$ & & $\$$ & 247.08 & $2.0 \%$ & & & $\$$ & 2.74 & $36 \%$ \\
\hline 1988 & $\$ 28.28$ & $49 \%$ & & $\$$ & 277.72 & $12.4 \%$ & & & $\$$ & 3.91 & $43 \%$ \\
\hline 1989 & $\$ \quad 28.58$ & $1 \%$ & & $\$$ & 350.40 & $26.2 \%$ & & & $\$$ & 3.63 & $-7 \%$ \\
\hline 1990 & $\$ 20.47$ & $-28 \%$ & & $\$$ & 330.22 & $-5.8 \%$ & & & $\$$ & 2.31 & $-36 \%$ \\
\hline 1991 & $\$ 21.18$ & $3 \%$ & $39 \%$ & $\$$ & 417.09 & $26.3 \%$ & $288 \%$ & $14.2 \%$ & $\$$ & 2.62 & $13 \%$ \\
\hline 1992 & $\$ 20.85$ & $-2 \%$ & $79 \%$ & $\$$ & 435.71 & $4.5 \%$ & $364 \%$ & $21.7 \%$ & $\$$ & 4.17 & $59 \%$ \\
\hline 1993 & $\$ 28.52$ & $37 \%$ & $49 \%$ & $\$$ & 466.45 & $7.1 \%$ & $385 \%$ & $12.9 \%$ & $\$$ & 6.46 & $55 \%$ \\
\hline 1994 & $\$ 37.45$ & $31 \%$ & $158 \%$ & $\$$ & 459.27 & $-1.5 \%$ & $325 \%$ & $49.0 \%$ & $\$$ & 5.86 & $-9 \%$ \\
\hline 1995 & $\$ 37.99$ & $1 \%$ & $122 \%$ & $\$$ & 615.93 & $34.1 \%$ & $354 \%$ & $33.9 \%$ & $\$$ & 6.23 & $6 \%$ \\
\hline 1996 & $\$ 51.86$ & $37 \%$ & $119 \%$ & $\$$ & 740.74 & $20.3 \%$ & $504 \%$ & $23.9 \%$ & $\$$ & 7.34 & $18 \%$ \\
\hline 1997 & $\$ 51.88$ & $0 \%$ & $782 \%$ & $\$$ & 970.43 & $31.0 \%$ & $590 \%$ & $132.8 \%$ & $\$$ & 11.38 & $55 \%$ \\
\hline 1998 & $\$ \quad 48.25$ & $-7 \%$ & $504 \%$ & $\$$ & $1,229.23$ & $26.7 \%$ & $645 \%$ & $78.1 \%$ & $\$$ & 21.56 & $89 \%$ \\
\hline 1999 & $\$ 88.69$ & $84 \%$ & $1335 \%$ & $\$$ & $1,469.25$ & $19.5 \%$ & $779 \%$ & $174.2 \%$ & $\$$ & 20.23 & 070 \\
\hline 2000 & $\$ 57.62$ & $-35 \%$ & $622 \%$ & $\$$ & $1,320.28$ & $-10.1 \%$ & $525 \%$ & $115.0 \%$ & $\$$ & 18.90 & $17 \%$ \\
\hline 2001 & $\$ 46.94$ & $-19 \%$ & $165 \%$ & $\$$ & $1,148.08$ & $-13.0 \%$ & $374 \%$ & $45.8 \%$ & $\$$ & 11.80 & $-38 \%$ \\
\hline 2002 & $\$ \quad 49.22$ & $5 \%$ & $159 \%$ & $\$$ & 879.82 & $-23.4 \%$ & $256 \%$ & $58.2 \%$ & $\$$ & 7.22 & $-39 \%$ \\
\hline 2003 & $\$ 64.47$ & $31 \%$ & $128 \%$ & $\$$ & $1,111.92$ & $26.4 \%$ & $300 \%$ & $44.1 \%$ & $\$$ & 12.96 & $80 \%$ \\
\hline 2004 & $\$ 77.65$ & $20 \%$ & $172 \%$ & $\$$ & $1,211.92$ & $9.0 \%$ & $246 \%$ & $70.7 \%$ & $\$$ & 12.12 & $-6 \%$ \\
\hline 2005 & $\$ 100.69$ & $30 \%$ & $392 \%$ & $\$$ & $1,248.29$ & $3.0 \%$ & $278 \%$ & $138.6 \%$ & $\$$ & 7.34 & $-39 \%$ \\
\hline 2006 & $\$ 129.26$ & $28 \%$ & $510 \%$ & $\$$ & $1,418.30$ & $13.6 \%$ & $240 \%$ & $193.8 \%$ & $\$$ & 6.78 & $-8 \%$ \\
\hline 2007 & $\$ 104.14$ & $-19 \%$ & $399 \%$ & $\$$ & $1,411.63$ & $-0.5 \%$ & $224 \%$ & $167.3 \%$ & $\$$ & 5.46 & $-19 \%$ \\
\hline 2008 & $\$ 65.08$ & $-38 \%$ & $128 \%$ & $\$$ & 903.25 & $-36.0 \%$ & $94 \%$ & $55.5 \%$ & $\$$ & 2.19 & $-60 \%$ \\
\hline 2009 & $\$ 84.16$ & $29 \%$ & $125 \%$ & $\$$ & $1,115.10$ & $23.5 \%$ & $143 \%$ & $49.2 \%$ & $\$$ & 8.90 & $306 \%$ \\
\hline 2010 & $\$ 78.63$ & $-7 \%$ & $107 \%$ & $\$$ & $1,257.64$ & $12.8 \%$ & $104 \%$ & $61.6 \%$ & $\$$ & 14.95 & $8 \%$ \\
\hline 2011 & $\$ 66.13$ & $-16 \%$ & $28 \%$ & $\$$ & $1,257.60$ & $0.0 \%$ & $70 \%$ & $20.2 \%$ & $\$$ & 9.58 & $-36 \%$ \\
\hline 2012 & $\$ 93.25$ & $41 \%$ & $80 \%$ & $\$$ & $1,426.19$ & $13.4 \%$ & $47 \%$ & $88.0 \%$ & $\$$ & 11.74 & $23 \%$ \\
\hline 2013 & $\$ 121.92$ & $31 \%$ & $153 \%$ & $\$$ & $1,848.36$ & $29.6 \%$ & $50.4 \%$ & $303.1 \%$ & $\$$ & 14.36 & $22 \%$ \\
\hline 201 & 125.48 & $3 \%$ & $\%$ & $\$$ & $2,059.00$ & $11 \%$ & $0.1 \%$ & $3.3 \%$ & & & \\
\hline
\end{tabular}

*stock prices adjusted for splits and dividends (Yahoo! Finance)

\begin{tabular}{|l|l}
\hline & Pre-Good to Great Era (1984-1998) \\
Good to Great Era (1999-2013) \\
Highlighted 15 cumulative return comparison
\end{tabular}




\section{Copyright Disclaimer}

2016, Vol. 8, No. 3

Copyright for this article is retained by the author(s), with first publication rights granted to the journal.

This is an open-access article distributed under the terms and conditions of the Creative Commons Attribution license (http://creativecommons.org/licenses/by/3.0/). 